\title{
Occurrence of Foliar Pathogens of Watermelon on Commercial Farms in South Carolina Estimated with Stratified Cluster Sampling
}

Gabriel Rennberger, ${ }^{\dagger}$ Clemson University, Coastal Research and Education Center, Charleston, SC 29414; Patrick Gerard, Clemson University, Department of Mathematical Sciences, Clemson, SC 29634; and Anthony P. Keinath, Clemson University, Coastal Research and Education Center, Charleston, SC 29414

\begin{abstract}
A survey of foliar pathogens of watermelon based on two-stage cluster sampling was conducted on commercial farms in South Carolina in spring 2015, spring and fall 2016, and fall 2017. In total, 60 fields from 27 different growers in seven counties representing the main watermelon-producing areas in the state were sampled, using a stratified two-stage cluster sampling approach. In the sampling design, counties corresponded to strata, growers to first-stage clusters, and fields to second-stage clusters. In each field, 100 symptomatic leaves were collected at five equidistant sampling points along four transects encompassing a square shape of $2,500 \mathrm{~m}^{2}$. After collection, pathogens were identified based on reproductive structures formed on leaves during $>12 \mathrm{~h}$ incubation. Estimates were obtained for the statewide probability of pathogen occurrence and associations between pathogen pairs. Six fungal pathogens, Stagonosporopsis spp., Podosphaera xanthii, Cercospora citrullina, Colletotrichum orbiculare, Myrothecium sensu lato (s.1.), and Corynespora cassiicola; the oomycete Pseudoperonospora cubensis; and three viral pathogens were identified on the examined leaves. With the exception of fall 2017, Stagonosporopsis spp. was the

most prevalent pathogen in every season, followed by $P$. xanthii. The highest occurrence of $P$. cubensis was in spring 2015; it did not occur in 2016. The highest occurrence of $C$. orbiculare was in spring 2016 it did not occur in spring 2015. Myrothecium s.l. was the most common pathogen in fall 2017 and the second most common pathogen occurring by itself in fall 2016. The third most common pathogen in fall 2017 Corynespora cassiicola, was not observed in any other season. Eight of the 80 isolates of Stagonosporopsis spp. collected were identified as $S$. caricae, the rest as $S$. citrulli. All isolates of $S$. caricae were found in spring 2015 and originated from two fields in different counties. A total of three positive and five negative associations were found between pathogen pairs co-occurring on the same leaf. A positive association between Stagonosporopsis spp. and C. citrullina was the only significant association between pathogens found in two seasons, spring 2015 and spring 2016. Based on estimates of probability of pathogen occurrence across seasons, Stagonosporopsis spp. and $P$. xanthii are the most common pathogens on watermelons in South Carolina. This is the first report of C. cassiicola, S. caricae, and Myrothecium s.l. on watermelon in South Carolina.
\end{abstract}

Watermelon is an important vegetable crop in South Carolina, which ranks fifth in the United States in watermelon production (USDA 2014). With 2,298 ha grown across all 46 counties of the state, the majority of the production is concentrated in the southern parts of the central and coastal plains of the state. The most common production system is raised beds covered with polyethylene mulch and drip irrigation. The main harvest season is in June and July, but an additional crop may be harvested in September and October. In the southeastern United States, the crop takes approximately 78 to 91 days from transplanting to harvest (Kemble et al. 2018).

On cucurbits, 13 foliar diseases are caused by fungi and oomycetes (Keinath et al. 2017).

Gummy stem blight (GSB) is caused by three genetically distinct but morphologically indistinguishable fungal species of Stagonosporopsis. S. citrulli and S. cucurbitacearum (syn. Didymella bryoniae) are host-specific to cucurbits, whereas $S$. caricae also infects papaya (Carica papaya). S. citrulli has the widest distribution, whereas $S$. cucurbitacearum occurs only in temperate regions (Stewart et al. 2015). The disease can affect all aboveground plant parts. On leaves, typical symptoms are circular to triangular, tan to dark brown, water-soaked lesions. Stagonosporopsis spp. produce tan to brown pycnidia and brown to black pseudothecia. A temperature

\section{${ }^{\dagger}$ Corresponding author: G. Rennberger; E-mail: grennbe@clemson.edu}

Funding: This material is based upon work that is supported in part by the National Institute of Food and Agriculture, U.S. Department of Agriculture, under project number SC-1700536 and the Agricultural Marketing Service, U.S. Department of Agriculture, under prime grant agreement \#15-SCBGPSC-0013. Technical Contribution number 6634, Clemson University Experiment Station.

Accepted for publication 28 April 2018.

@ 2018 The American Phytopathological Society of $16-28^{\circ} \mathrm{C}$ and leaf wetness of $>1 \mathrm{~h}$ are necessary for infection, and lesion expansion requires continuous leaf wetness. Moisture is generally more important than temperature for disease development (Keinath 2017b).

Powdery mildew is a major cucurbit disease with worldwide distribution mainly caused by the fungi Podosphaera xanthii and Golovinomyces cichoracearum, with $P$. xanthii being the most commonly reported pathogen in the southeastern United States. Cucurbit powdery mildew fungi are obligate parasites that are mainly dispersed via airborne conidia. Symptoms can develop on both leaf surfaces, petioles, and stems, and are characterized by white powdery growth (McGrath 2017).

Cercospora leaf spot is caused by the fungus Cercospora citrullina, a taxon that may be a species complex (Everts 2017; Groenewald et al. 2013). The disease is commonly found on watermelon and other cucurbits (Everts et al. 2016). Tan to brown, small, circular leaf spots are the main symptom of this disease. Crop debris and cucurbitaceous weeds serve as overwintering sites, and spores of the pathogen can be transported long distances when airborne. Conidiophores of $C$. citrullina are pale brown, not branched, and mostly form in groups of 2-5 stalks. Conidia are hyaline, multiseptate, up to $240 \mu \mathrm{m}$ in length, and wider at their base (Everts 2017).

The oomycete Pseudoperonospora cubensis is the causal agent of downy mildew, one of the most important diseases of cucurbits. In the United States, its resurgence in 2004 caused substantial crop losses in cucumber production, despite the use of cultivars that were resistant prior to the disease outbreak in 2004. Symptoms of downy mildew can differ greatly depending on the affected cucurbit species. General symptoms and signs on cucurbits other than cucumber manifest themselves as small, irregular-shaped lesions on the upper leaf surface accompanied by sporulation on the lower leaf surface (Hausbeck 2017; Holmes et al. 2015). Characteristic for P. cubensis are dichotomously branched, hyaline sporangiophores and purplish, ovoid to ellipsoid sporangia (Hausbeck 2017). As a biotrophic pathogen, $P$. cubensis is unable to survive winters in regions where host 
plants are absent (north of the 30th latitude). The presence and spread of the disease is therefore dependent on the yearly long-distance transport of spores from source regions in the southern United States. Whether a crop in a given field is infected depends on the number of viable spores in the air surrounding the field, which is dependent on the number of spores that are released from the source field and their dilution and survival during transport (Neufeld et al. 2018). Recently, isolates of both mating types of the pathogen collected in the southern United States were shown to be capable of producing oospores on cucumber and cantaloupe. Considering this finding, it appears possible that $P$. cubensis might also overwinter as oospores in the southern United States (Thomas et al. 2017b).

Anthracnose is a common disease of watermelon caused by the fungus Colletotrichum orbiculare. There are three races of C. orbiculare, of which race 2 infects all watermelon cultivars. Openpollinated and heirloom cultivars are also susceptible to races 1 and 2B (Keinath 2015a; Wasilwa et al. 1993). On leaves, anthracnose lesions are dark brown, angular, and can appear as typical "shotholes." Anthracnose lesions may also affect petioles, vines, and fruits of susceptible cucurbits. Conidia appear as typical salmon-colored spore masses on acervuli and are disseminated predominantly by rain splashes and wind. A minimum of $2 \mathrm{~h}$ of leaf wetness is required for infection, but no additional leaf wetness is necessary for lesion expansion (Keinath 2017a).

Target spot is a plant disease caused by the fungus Corynespora cassiicola. The host range of this pathogen is very wide, with more than 530 plant species and even reports of infected human skin and corneas (Dixon et al. 2009; Mahgoub 1969; Yamada et al. 2013). Among cucurbits, cucumbers are most commonly affected, and symptoms on leaves appear as small, angular, water-soaked lesions. C. cassiicola overwinters on crop debris and is disseminated through airborne conidia. The conidiophores of $C$. cassiicola appear iridescent and pale gray or brown. Conidia are born singly or in short chains, pale brown to brown, characteristically pseudoseptate and with a distinct hilum on the end. Conditions of high humidity, temperatures of 25 to $35^{\circ} \mathrm{C}$, and free moisture on plants promote infection by C. cassiicola and disease development (Williams and Vallad 2017).

Myrothecium leaf spot is a disease caused by one or more species in the species complex Myrothecium sensu lato (s.l.) (Bruton and Fish 2017; Lombard et al. 2016). In addition to the foliar phase, the disease can affect crowns, stems, and fruits, then referred to as crater rot. Lesions on leaves are round to irregular-shaped and often form concentric rings with abundant olive green to black spore masses on sporodochia (Bruton and Fish 2017).

The literature on surveys of cucurbit diseases is scarce. The majority of surveys have been conducted on viruses that affect cucurbitaceous crops (Ali et al. 2012; Coutts and Jones 2005; Köklü and Yilmaz 2006; Papayiannis et al. 2005; Sammons et al. 1989; Ullman et al. 1991). Only two of these studies were conducted on the United States mainland, and none of the results were analyzed statistically (Ali et al. 2012; Sammons et al. 1989). In the past 20 years, only one survey of foliar diseases of a cucurbit crop was conducted in the southeastern United States. Over the course of three seasons in the late 1990s, Peterson and Campbell (2002) examined 5,400 leaves with leaf spots collected from cucumber fields from 11 counties in North Carolina. Although the number of examined leaves was sufficient and the collection of leaves within a given field was appropriate, there were some shortcomings in their survey. The sampled fields were not selected systematically based on probability, and it is not clear how many fields per county were sampled. The results of pathogen occurrence were not analyzed statistically (Peterson and Campbell 2002).

Despite the lack of accurate field data of pathogen occurrence, watermelon diseases and their management were ranked as top priorities in a recent opinion survey of researchers and extension specialists. Fusarium wilt and GSB were regarded as most pressing issues in watermelon production, followed by anthracnose, Cucumber green mottle mosaic virus, and powdery mildew (Kousik et al. 2016). Due to the fact that different fungicides and management strategies are needed to control different cucurbit pathogens, accurate information about their occurrence on commercial farms is crucial to improve recommendations for growers (Keinath 2018; Kemble et al. 2018)

In stratified sampling, the population is subdivided into disjoint subpopulations called strata that encompass the entire population. A simple random sample (SRS) is then taken from each stratum. Each sampling unit is a member of only one stratum. Stratified sampling has the advantage of avoiding unrepresentative samples and providing generally more precise estimates than SRS, especially when there are substantial differences among strata. In cluster sampling, the population is divided into groups of units, which are called clusters. Often, there are secondary sampling units within the clusters. In 1-stage-cluster sampling, a SRS of clusters is taken, and all units within the chosen clusters are observed. In 2-stage-cluster sampling, a SRS of units within the chosen first-stage clusters is taken, but not all units within the chosen clusters are observed. Cluster sampling is used for geographically widespread sampling units, because collection time and costs can be limited. However, the precision of estimators in cluster sampling is typically decreased compared with SRS. Cluster sampling is most efficient when the clusters are relatively homogeneous. Stratification and clustering can be combined in sampling designs to fit specific circumstances (Rao 2000).

The objectives of this study were to i) determine the most prevalent foliar pathogens of watermelons in South Carolina, ii) compare the occurrence of foliar pathogens between the selected counties and fields and characterize the differences between them, and iii) investigate associations between pathogens. By using a complex sampling design with stratification, clustering, and appropriate statistical analysis methods specifically designed for survey data, representative statewide estimates of pathogen occurrence were obtained.

\section{Materials and Methods}

Sampling design. A stratified two-stage cluster sampling design was used to sample symptomatic watermelon leaves from commercial fields in 2015 and 2016. In 2016, both spring and fall crops were sampled. The strata were preselected counties with the highest recorded watermelon acreage in South Carolina (USDA-NASS 2014). Six counties were sampled in 2015, seven in the spring of 2016, and six in the fall of 2016 (Table 1). In fall 2017, only two growers in Beaufort County grew watermelons. Two fields from each of those two growers were sampled. Thus, the sampling in fall 2017 lacked stratification and a second layer of clustering and was therefore a simple cluster sample among the fields of each of the two growers.

Growers, who were selected randomly from a compiled list obtained from Clemson Cooperative Extension agents, represented the first level of clustering within each county. Sixteen, 17, 7, and 2 different growers were included in spring 2015, spring 2016, fall 2016, and fall 2017, respectively. In total, fields from 27 different growers were sampled, of which one was sampled in all four seasons; one was sampled in 2015, spring 2016, and fall 2016; eight were sampled in both spring 2015 and 2016; one was sampled in both seasons of 2016; one was sampled in fall 2016 and fall 2017; six growers were sampled only in 2015; six growers were sampled only in spring 2016; and three growers were sampled only in fall 2016 (Fig. 1).

The randomly selected fields represented the second level of clustering in the sampling design. In 2015 leaves were collected from a total of 21 fields, in the spring of 2016 from 24 fields, and in the fall of 2016 from 11 fields (Table 1). The number of fields sampled per county was assigned using proportional allocation based on the watermelon acreage per county (Rao 2000). If a grower had one watermelon field, that field was sampled; if the grower had two fields, one was chosen randomly; if the grower had three or four fields, two were chosen randomly; and if the grower had five or more fields, three were chosen randomly. All fields were sampled within 1 week of harvest starting or ending.

A square shape consisting of four perpendicular transects $50 \mathrm{~m}$ in length that encompassed an area of $2,500 \mathrm{~m}^{2}(0.62 \mathrm{ac})$ was sampled in each field. The size of the sampled fields ranged from 0.81 to 22.67 ha. The location within each field was chosen away from the edges of the field if possible. Along each transect, five leaves with spots were 
collected at each of five sampling points spaced $10 \mathrm{~m}$ apart, resulting in a total of 20 sampling points and 100 leaves collected per field (Fig. 2). Additional information about cultivar and fungicides applied within 7 days and within 7 to 14 days prior to sampling was obtained from growers. GPS coordinates for each field were determined and saved prior to sampling. To prevent confounding of the factor county with sampling date and plant age, samples from at least two counties were taken on any given sampling day in spring and fall of 2016.

Leaf processing. Leaves from each sampling point were placed in a separate plastic bag and transferred to a cooler after sampling of a field was completed. Upon arrival at the laboratory, bags with leaves from 1 to 2 fields were incubated under constant light and high relative humidity for 12 to $25 \mathrm{~h}$. Remaining samples were stored at $8^{\circ} \mathrm{C}$ until initial samples were processed, incubated, and examined, so that all leaves collected on an individual sampling day were processed within $72 \mathrm{~h}$ after collection. Leaves were examined with a stereomicroscope at $7 \times$ to $45 \times$ magnification, and reproductive structures observed were used for identification of pathogens. Presence of pathogens was recorded for each leaf. When no pathogens could be identified on any leaf from a sampling point, one lesion from each of four leaves per sampling point was surface disinfested in $0.825 \%$ sodium hypochlorite for $60 \mathrm{~s}$, rinsed in autoclaved deionized water, and placed onto quarter-strength potato dextrose agar (QPDA) amended with $0.1 \mathrm{~g} /$ liter chloramphenicol, $0.1 \mathrm{~g} /$ liter streptomycin, and $45.3 \mu 1 /$ liter mefenoxam (Ridomil Gold SL, Syngenta) for pathogen recovery (Keinath 2008). Four leaves from each sampling point were cultured for all four fields that were sampled in fall 2017. Because of the large number of leaves with typical symptoms of GSB but no signs of the pathogen in spring 2015 and spring 2016, the number of leaves in this category were recorded in fall 2016 and fall 2017. For identification of powdery mildew fungi, conidia of three isolates from each of spring 2015 and spring 2016 were mounted in $3 \%$ aqueous potassium hydroxide and examined microscopically for the presence of fibrosin bodies (Kable and Ballantyne 1963).

Molecular identification. In fall 2016, in fields where symptoms of viral diseases were found, a subsample of 10 leaves per field was sent to a commercial laboratory (Agdia Incorporated, Elkhart, IN) for ELISA testing with specific antibodies for 14 viruses pathogenic to watermelon and a general antibody for the Potyvirus group. Identification of the begomovirus found in fall 2017 is in progress (Keinath et al., unpublished). Isolates of Stagonosporopsis spp. obtained as described above were stored on dried filter paper at $-20^{\circ} \mathrm{C}$ in the dark until further use. In total, 80 isolates representing five fields, four growers, and three seasons (Table 2) were saved for species identification with a multiplex polymerase chain reaction (PCR) assay (Brewer et al. 2015). Briefly, agar plugs of actively growing cultures were transferred to plastic containers containing autoclaved $2.4 \%$ potato dextrose broth and incubated in the dark for 7 days at $22^{\circ} \mathrm{C}$. Mycelium was harvested and added to $2-\mathrm{ml}$ tubes containing a ceramic bead, two scoops of fine sand, and $500 \mu \mathrm{l}$ of lysis buffer $(400 \mathrm{mM}$ Tris [pH 8], $60 \mathrm{mM}$ EDTA [pH 8], $150 \mathrm{mM} \mathrm{NaCl}$ ). Tissue was lysed for two cycles of $20 \mathrm{~s}$ in a bead beater (FastPrep-24, M.P. Biomedicals, Irvine, CA), after which $50 \mu \mathrm{l}$ of $10 \%$ sodium dodecyl sulfate was added and vortexed. After $10 \mathrm{~min}$ at room temperature, $150 \mu \mathrm{l}$ of potassium acetate $(\mathrm{pH} \mathrm{4.8)}$ was added to the sample, vortexed, and centrifuged at $10,000 \times g$ for $1 \mathrm{~min}$. The supernatant was removed, $10 \mu \mathrm{l}$ of RNase A was added, and samples were incubated at $37^{\circ} \mathrm{C}$ for $20 \mathrm{~min}$. Subsequently, samples were centrifuged again at $10,000 \times g$ for $1 \mathrm{~min}$, and the supernatant $(600 \mu \mathrm{l})$ was added to $600 \mu \mathrm{l}$ of isopropanol and gently mixed by inversion for $1 \mathrm{~min}$ followed by centrifuging at $10,000 \times g$ for $2 \mathrm{~min}$. The supernatant was discarded, and the DNA pellet was rinsed with $70 \%$ ethanol, dried, and resuspended in $50 \mu$ l of sterile water. The concentration of the extracted DNA was measured using the Qubit dsDNA BR Assay Kit (Invitrogen, Thermo Fisher Scientific, Waltham, MA) according to the manufacturer's instructions. The extracted DNA was adjusted to a concentration of $10 \mathrm{ng} / \mu \mathrm{l}$ and used as template in the PCR reactions.

The three primer pairs Db01F (5'-CGGTCCGGTCAACCTAC TAC-3') and Db01R (5'-CACGCCAGCAAATCTCACTA-3'), Db05F (5'-TATGACGTTGGGCAAGTGAG-3') and Db05R (5'TTTGCTGGGATGGTGTTGTA-3'), and Db06F (5'-GGTGACATCTT GCGTGAATG-3') and Db06R (5'-TGGTTGTTTGGTTGTTTGGA-3')

Table 1. Watermelon fields sampled in four seasons from 2015 to 2017 in South Carolina

\begin{tabular}{|c|c|c|c|c|c|c|}
\hline $\begin{array}{l}\text { Season, } \\
\text { year }\end{array}$ & County & $\begin{array}{c}\text { Acreage } \\
\text { (ha) }\end{array}$ & $\begin{array}{c}\text { Number of growers in } \\
\text { county }\end{array}$ & $\begin{array}{c}\text { Number of growers } \\
\text { selected }^{\mathbf{a}}\end{array}$ & $\begin{array}{c}\text { Number of fields of growers } \\
\text { selected }\end{array}$ & $\begin{array}{c}\text { Number of fields } \\
\text { sampled }^{\mathbf{b}}\end{array}$ \\
\hline \multirow{6}{*}{$\begin{array}{r}\text { Spring } \\
2015\end{array}$} & Bamberg & 262 & 6 & 4 & 13 & 4 \\
\hline & Barnwell & 379 & 6 & 5 & 7 & 5 \\
\hline & Beaufort & 273 & 3 & 2 & 11 & 4 \\
\hline & Clarendon & 103 & 1 & 1 & 1 & 1 \\
\hline & Colleton & 285 & 4 & 2 & 14 & 4 \\
\hline & Hampton & 211 & 5 & 3 & 3 & 3 \\
\hline Subtotal & & & 25 & 17 & 49 & 21 \\
\hline \multirow{7}{*}{$\begin{array}{r}\text { Spring } \\
2016\end{array}$} & Allendale & 102 & 4 & 1 & 3 & 1 \\
\hline & Bamberg & 262 & 17 & 3 & 13 & 4 \\
\hline & Barnwell & 379 & 9 & 5 & 8 & 6 \\
\hline & Beaufort & 273 & 2 & 2 & 4 & 4 \\
\hline & Clarendon & 103 & 4 & 2 & 4 & 2 \\
\hline & Colleton & 285 & 4 & 3 & 23 & 4 \\
\hline & Hampton & 211 & 6 & 3 & 7 & 3 \\
\hline Subtotal & & & 46 & 19 & 62 & 24 \\
\hline \multirow[t]{6}{*}{ Fall 2016} & Allendale & 102 & 1 & 1 & 3 & 1 \\
\hline & Bamberg & 262 & 4 & 2 & 2 & 2 \\
\hline & Barnwell & 379 & 1 & 1 & 1 & 1 \\
\hline & Beaufort & 273 & 2 & 1 & 5 & 2 \\
\hline & Colleton & 285 & 2 & 2 & 6 & 3 \\
\hline & Hampton & 211 & 1 & 1 & 3 & 2 \\
\hline Subtotal & & & 11 & 8 & 20 & 11 \\
\hline Fall 2017 & Beaufort & 273 & 2 & 2 & 20 & 4 \\
\hline
\end{tabular}

${ }^{a}$ The growers were chosen randomly from a list of all growers in a county.

$\mathrm{b}$ The total number of fields to be sampled in a season was predefined at the beginning of each sampling season. The number of fields sampled in a county was calculated using proportional allocation based on the watermelon acreage in the county. Fields were chosen randomly from all fields of a selected grower. 
were used in the multiplex PCR. These primers produce specific bands for each of the three species of Stagonosporopsis. The DbO1 locus is only amplified in $S$. citrulli, Db06 amplifies fragments of S. citrulli and S. cucurbitacearum, and Db05 amplifies fragments in all three species (Brewer et al. 2015). A total volume of $15 \mu \mathrm{l}$ was used for the PCR reactions. The reactions consisted of $3 \mu \mathrm{l}$ of $10 \times$ buffer, $1.5 \mu \mathrm{l}$ dNTPs, $0.09 \mu \mathrm{l}$ of GoTaq (Promega, Madison, WI), $0.75 \mu \mathrm{l}$ of each primer, and $1 \mu \mathrm{l}$ of DNA template. In each PCR, reactions with DNA of isolates with known species identity were included as controls. Isolate RV16 served as control for $S$. caricae, isolate GSB19 for S. cucurbitacearum, and isolate C68 for $S$. citrulli (Brewer et al. 2015; Stewart et al. 2015). Thermal cycling was initiated by denaturation at $94^{\circ} \mathrm{C}$ for $2 \mathrm{~min}$. This was followed by 35

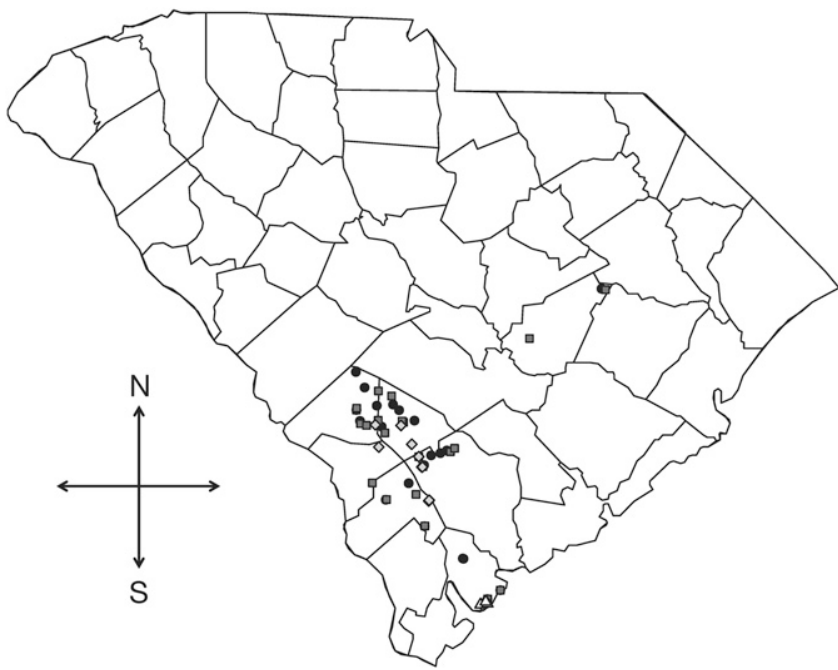

Fig. 1. Locations of the 60 fields sampled in four seasons from 2015 to 2017. Black circles $=21$ fields sampled in spring 2015. Dark gray squares $=24$ fields sampled in spring 2016. Light gray diamonds $=11$ fields sampled in fall 2016. White triangles $=4$ fields sampled in fall 2017 .

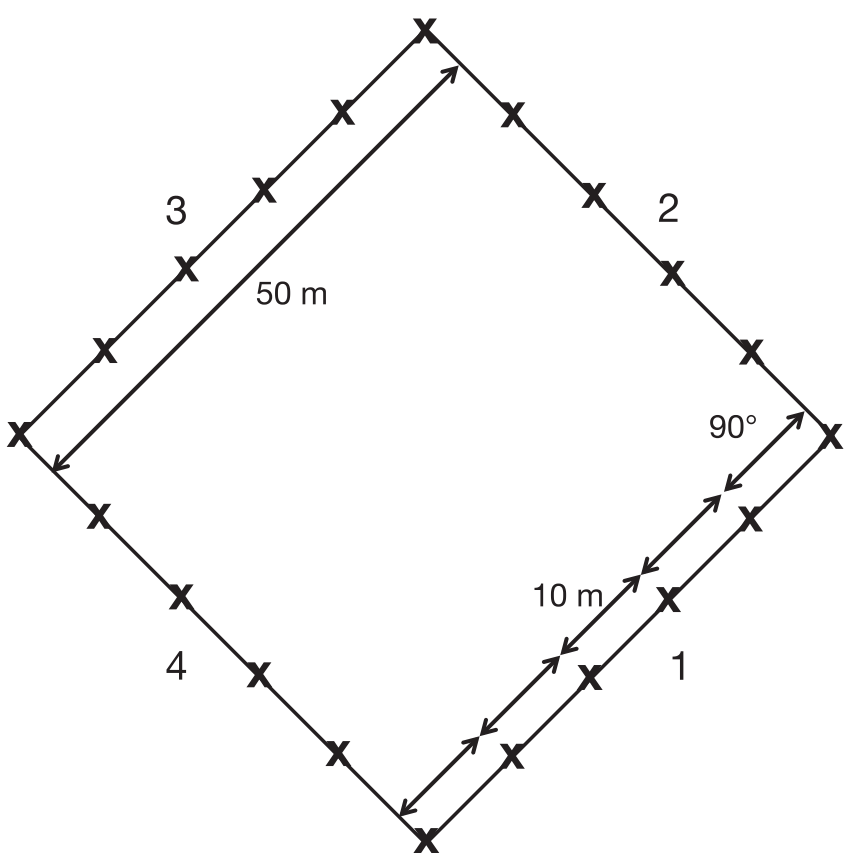

Fig. 2. Sampling scheme within a selected field. Five symptomatic leaves were collected at each of five sampling points along four transects $50 \mathrm{~m}$ in length perpendicular to one another. Sampling points were equally distanced from one another with a sampling interval of $10 \mathrm{~m}$ between points. Transects start at the corners of a square encompassing $2,500 \mathrm{~m}^{2}(0.62 \mathrm{ac})$. Numbers 1 to 4 indicate order of transects. cycles of $94^{\circ} \mathrm{C}$ for $30 \mathrm{~s}, 55^{\circ} \mathrm{C}$ for $30 \mathrm{~s}$, and $72^{\circ} \mathrm{C}$ for $30 \mathrm{~s}$. A final step of $72^{\circ} \mathrm{C}$ for 5 min completed the PCR. The entire volume of amplified product was separated on a $2.5 \%$ (wt/vol) agarose gel containing $1 \times$ SYBR Safe nucleic acid gel stain (Invitrogen, Thermo Fisher Scientific), which was run at $95 \mathrm{~V}$ for $2 \mathrm{~h}$ and visualized with a molecular imager (Gel Doc XR+, Bio-Rad Laboratories Inc., Hercules, CA).

Data analysis. SAS (SAS Institute Inc., Cary, NC) statistical software was used for all analyses. PROC SURVEYMEANS was used to obtain estimates of the overall proportions of pathogen occurrence on leaves with spots. The county a given sample was collected from was specified as stratum variable, and the grower was specified as cluster variable. The incidence of a pathogen was the response variable, and proportions were estimated separately for each pathogen. Sampling weights were specified to account for the probability of choosing a particular field. They were calculated with the following formula: $w=1 /\left(\left(a^{*} b\right) /\left(c^{*} d\right)\right)$, where $a=$ the number of selected growers within a county, $b=$ number of selected fields within the county in $a, c=$ total number of growers of the county in $a$, and $d=$ total number of fields of the county in $a$ (Table 1). In a combined analysis, data from all seasons were analyzed together by including each county-season combination as a separate stratum. In order to compare the estimates of overall pathogen occurrence, SAS PROC SURVEYMEANS was used to calculate $95 \%$ confidence intervals for the differences in occurrence between pathogen pairs. These differences were computed separately for each field. Associations between pathogen pairs on each leaf were calculated with PROC SURVEYFREQ for each season. Strata and cluster variables and sampling weights were accounted for in the analysis as described for estimation of overall means. The CHISQ option was used to calculate Rao-Scott Chi-Square tests for each pathogen combination (Rao and Scott 1981, 1984, 1987).

\section{Results}

Environmental conditions during sampling. The average temperatures prevailing in the months during which the sampling was carried out were all elevated compared with the 30-year average of the region (Table 3). In July and September 2016, the mean monthly temperature was more than $2^{\circ} \mathrm{C}$ higher than normal (National Weather Service Forecast Office 2018). In the other months, June and July 2015, June and October 2016, and September 2017, the mean temperatures were elevated from 0.6 to $1.8^{\circ} \mathrm{C}$ compared with the 30-year average. Spring 2016 was an unusually dry season. In June and July, the total precipitation was 115.5 and $84.8 \mathrm{~mm}$ below that of the previous year, which amounts to 63.8 and $54.6 \mathrm{~mm}$ below the 30-year average, respectively. In contrast to that, the fall of 2016 was wetter than normal. Both September and October received $\geq 266 \mathrm{~mm}$ of total precipitation, which was 156.7 and $170.9 \mathrm{~mm}$ above the average for these months. June and July 2015 and September 2017 received precipitation only slightly above the average, ranging from 14.2 to $51.8 \mathrm{~mm}$ precipitation above the average (Table 3).

Occurrence of pathogens. In spring 2015, spring 2016, and fall 2017 , the highest percentage of leaves had no pathogen structures. The percentage of leaves without pathogens ranged from $24.1 \%$ in fall 2016 to $38.3 \%$ in fall 2017. Among leaves with only a single pathogen, the most common pathogen was by far Stagonosporopsis spp., which occurred at the highest frequency of all pathogens in spring 2015, spring 2016, and fall 2016. In fall 2016, signs of

Table 2. Isolates of Stagonosporopsis spp. collected throughout sampling of watermelon fields in 2015 to 2017

\begin{tabular}{llccc}
\hline Season, year & County & S. citrulli & S. caricae & Total number of isolates \\
\hline Spring 2015 & Barnwell & 15 & 5 & 20 \\
Spring 2015 & Beaufort & 11 & 3 & 14 \\
Spring 2016 & Hampton & 8 & 0 & 8 \\
Fall 2017 & Beaufort & 35 & 0 & 35 \\
Fall 2017 & Beaufort & 3 & 0 & 3 \\
Total & 3 & 72 & 8 & 80 \\
\hline
\end{tabular}


Stagonosporopsis spp. were present on $64.0 \%$ of all examined leaves $(n=1,100)$, and typical symptoms of GSB were found on an additional $19.6 \%$ of leaves. Based on the condition that leaves were only cultured when no pathogens could be identified on any of the five leaves from a given sampling point, $10.4 \%$ of the 48 leaves cultured in fall 2016 yielded Stagonosporopsis spp., while the rest yielded no plant-pathogenic fungi. In fall 2017, 61.5\% $(n=400)$ of the collected leaves exhibited symptoms of GSB, of which $42.7 \%$ showed signs of Stagonosporopsis spp. In order to obtain additional isolates of Myrothecium s.l. for future studies, all 400 leaves collected in fall 2017 were cultured. Stagonosporopsis spp. was recovered from $9.5 \%$ of those leaves.

Fibrosin bodies were present in conidia of all isolates of powdery mildew examined in 2015 and 2016, which confirmed their identity as $P$. xanthii (McGrath 2017). In spring 2015 and 2016, P. xanthii was the second most frequent pathogen observed. $P$. xanthii, however, occurred only about a third as often as Stagonosporopsis spp. in 2015. Out of the 21 fields sampled in spring 2015, Stagonosporopsis spp. was the most prevalent pathogen in 13 fields, and $P$. cubensis and $P$. xanthii each were the predominant pathogen in four of the remaining eight fields. In spring 2016, however, there were almost as many leaves with $P$. xanthii as with Stagonosporopsis spp. As in the previous season, Stagonosporopsis spp. was the most prevalent pathogen in 13 of the 24 fields, but $P$. xanthii was the most frequent in nine fields. In the other two fields, $C$. orbiculare was found most frequently. In fall 2016, Stagonosporopsis spp. was the most common pathogen occurring by itself, followed by Myrothecium s.l. In fall 2016, Stagonosporopsis spp., P. xanthii, or Myrothecium s.l. was the most prevalent pathogen in eight, two, and one field out of the 11 fields sampled, respectively. By itself, however, $P$. xanthii occurred on less than $2.5 \%$ of leaves in fall 2016, and in fall 2017 it was one of the two least frequent pathogens occurring without other pathogens. The occurrence of $P$. cubensis was highest in spring 2015 and rare in fall 2017. It was not observed at all in the two 2016 seasons. The percentage of leaves with only $C$. orbiculare was highest in spring 2016 and very low in fall 2016 and 2017. C. orbiculare was not observed in spring 2015. Myrothecium s.l. was the second most common pathogen occurring by itself in fall 2016 and the most common in fall 2017. It was not detected in 2015 and was infrequent in spring 2016. The third most common pathogen in fall 2017, Corynespora cassiicola, was not observed in any other season. Stagonosporopsis spp. and Myrothecium s.l. each were the most prevalent pathogens in two of the four fields that were sampled in fall 2017. In fall 2016, viral pathogens were found in two fields, one in Bamberg County and one in Barnwell County. Based on ELISA testing, watermelon plants in those two fields were coinfected by Papaya ringspot virus (PRSV) and Zucchini yellow mosaic virus (ZYMV). In fall 2017, a begomovirus was detected in two of the four fields sampled at low frequency ( 2 to $4 \%$ ).

Estimates for probability of statewide pathogen occurrence. Stagonosporopsis spp. was the pathogen most likely to occur in all seasons except in fall 2017, when Myrothecium s.l. had an equally high probability of occurrence (Fig. 3). From spring 2015 to spring

Table 3. Sampling intervals and monthly environmental conditions during sampling of watermelon leaves

\begin{tabular}{lllccc}
\hline Season, year & Month & Sampling dates & Max $\left({ }^{\circ} \mathbf{C}\right)^{\mathbf{a}}$ & ${\text { Min }\left({ }^{\circ} \mathbf{C}\right)^{\mathbf{a}}}$ & Total rainfall $(\mathbf{m m})^{\mathbf{a}}$ \\
\hline Spring 2015 & June & 23 June (first) & 33.1 & 22.7 & 195.3 \\
& July & 27 July (last) & 33.6 & 23.4 & 196.1 \\
Spring 2016 & June & 13 June (first) & 33.0 & 22.8 & 79.8 \\
& July & 14 July (last) & 35.3 & 24.9 & 111.3 \\
Fall 2016 & September & 20 September (first) & 31.3 & 21.8 & 311.7 \\
& October & 3 October (last) & 27.1 & 15.4 & 266.2 \\
Fall 2017 & September & 26 September & 30.4 & 20.3 & 171.5 \\
\hline
\end{tabular}

${ }^{a}$ Weather data for Charleston, SC, from National Weather Forecast Service Office, available at: weather.gov

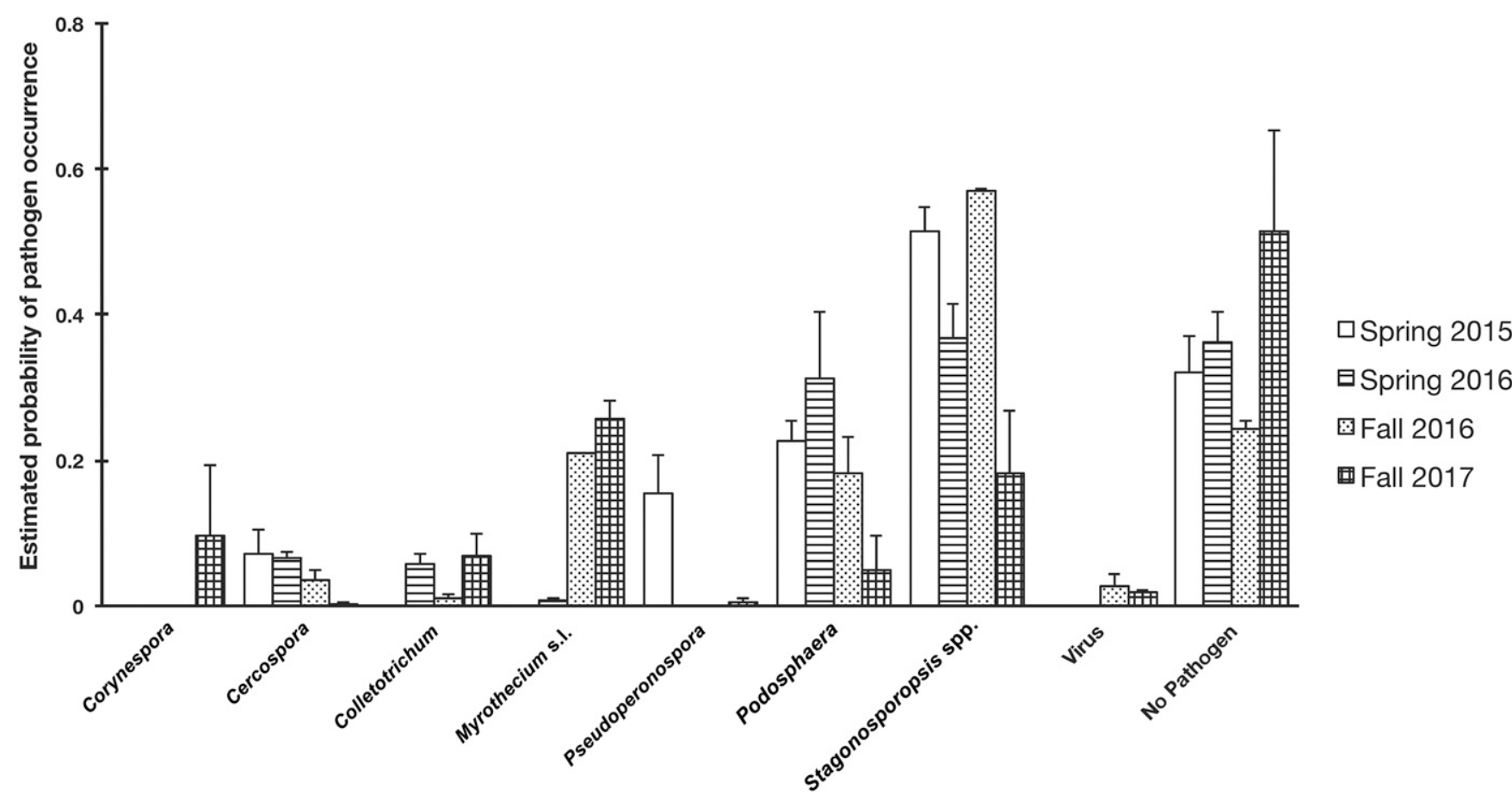

Fig. 3. Estimated probability of statewide pathogen occurrence in South Carolina by season 2015 to 2017. Error bars give standard errors calculated with SAS, PROC SURVEYMEANS 
2016, there was a marked decrease in the estimated probability of occurrence for Stagonosporopsis spp., which then increased to its highest level in fall 2016. The estimates for Stagonosporopsis spp. from the four fields that were sampled in fall 2017 were the lowest of all seasons. $P$. xanthii had the second highest estimates of occurrence in spring 2015 and spring 2016. In fall 2016, Myrothecium s.l. was as likely to occur as $P$. xanthii. With the exception of three leaves with Pseudoperonospora cubensis in fall 2017, this pathogen only occurred in spring 2015. That season, its likelihood of occurrence was comparable to that of P. xanthii. Cercospora citrullina and C. orbiculare both occurred in all seasons with very low probabilities of $\leq 7 \%$. In fall 2017, Myrothecium s.l. were the pathogens with the highest probability of occurrence. The causal agent of target spot of cucurbits, $C$. cassiicola, occurred only in fall 2017. Its probability of occurrence was low, but nonetheless it was the third highest among all observed pathogens that season. Viral pathogens were only found in fall 2016 and fall 2017. Both seasons, their probability of occurrence was among the lowest (Fig. 3).

Across seasons, the probability of occurrence for Stagonosporopsis spp. was significantly higher than for all other pathogens that were found throughout this survey (based on $95 \%$ confidence intervals) (Fig. 4). Only leaves with no pathogens were as likely to occur as leaves with Stagonosporopsis spp. Overall, $P$. xanthii was the pathogen second most likely to occur on watermelon leaves in South Carolina. It was significantly more likely to occur than any other pathogen except Stagonosporopsis spp. There was no statistical difference in the probability of occurrence among the four pathogens, C. citrullina, C. orbiculare, Myrothecium s.l., and P. cubensis, except that $C$. citrullina was significantly more likely to occur than $C$. orbiculare and P. cubensis. Their overall probabilities of occurrence ranged from 3.8 to $6.0 \%$. These pathogens were much less likely to occur than both Stagonosporopsis spp. and P. xanthii.
The remaining pathogens, $C$. cassiicola, PRSV, ZYMV, and begomovirus, were found in low frequencies in only one season and therefore were excluded from the combined analysis across seasons.

Species of Stagonosporopsis spp. Of the 80 isolates of Stagonosporopsis spp. identified to species during this study, eight were identified as $S$. caricae. The remaining 72 isolates were identified as $S$. citrulli. S. caricae was found in Barnwell and Beaufort counties in spring 2015 but not in 2016 or 2017 (Table 2). All isolates collected in Hampton County were identified as S. citrulli. Although in spring 2015, the incidence of $S$. caricae was $21.4 \%$ in the field sampled in Beaufort County, all 38 isolates collected in fall 2017 in Beaufort were $S$. citrulli. The fields sampled in these two seasons were from different growers. The incidence of $S$. caricae in the field in Barnwell County in spring 2015 was $25.0 \%$.

Associations between pathogens. A total of 7, 10, 7, and 11 different combinations of two pathogens occurred together on the same leaf in spring 2015 , spring 2016 , fall 2016 , and fall 2017 , respectively (Tables 4 and 5). The most common pathogen pair occurring together on the same leaf was $P$. xanthii and Stagonosporopsis spp. in all seasons. Combinations of three pathogens occurring together on the same leaf were observed on $<5 \%$ of sampled leaves in all seasons. There were 4, 6, 2, and 14 different combinations of three pathogens that occurred on the same leaf in the four seasons. A few leaves with four different pathogens were observed with one combination in spring 2015 and two different combinations in spring 2016 and fall 2017. Over the course of the entire study, there were a total of 19 , 21 , and 5 combinations of two, three, and four pathogens co-occurring on the same leaves (Tables 4 and 5).

Statistical analyses of the frequencies of pathogen occurrence revealed a number of significant associations between pathogen pairs (Table 6). In two seasons, spring 2015 and spring 2016, there was a positive association between Stagonosporopsis spp. and C. citrullina

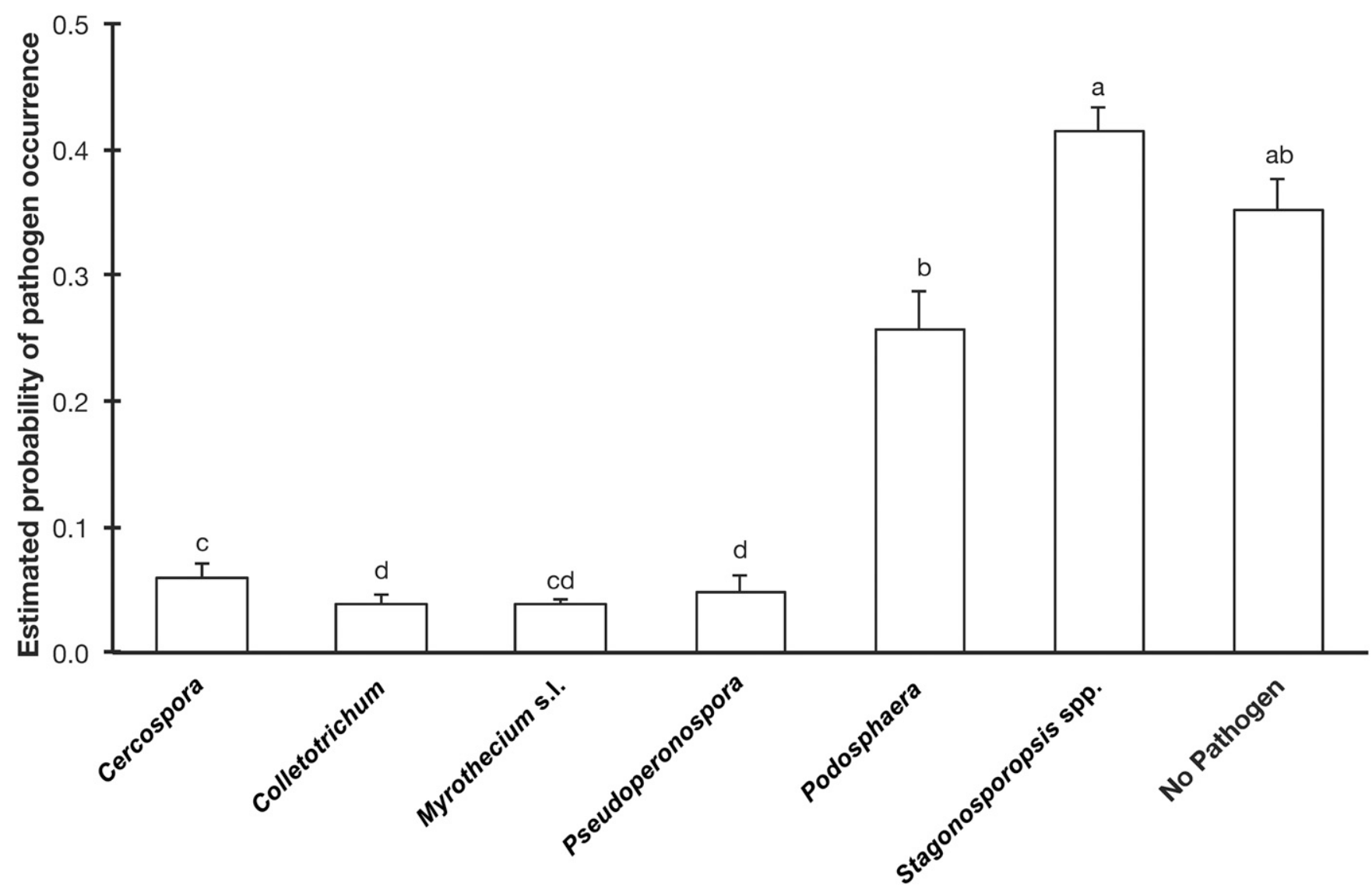

Fig. 4. Estimated probability of statewide pathogen occurrence across all four seasons 2015 to 2017. Error bars give one standard error calculated with SAS, PROC SURVEYMEANS. Mean separation is based on 95\% confidence intervals. Corynespora cassiicola and the viruses found in fall 2016 and fall 2017 were excluded from the combined analysis because each occurred in one season only. 
$(P<0.0001)$. When Stagonosporopsis spp. were present on a watermelon leaf, it was more likely for $C$. citrullina to be present than on leaves where Stagonosporopsis spp. was not present. In fall 2016, Stagonosporopsis spp. and $P$. xanthii also were positively associated with each other $(P<0.0001)$, meaning that when Stagonosporopsis spp. were present on a watermelon leaf, it was more likely for $P$. xanthii to be present. In spring 2016, there was a negative association between Stagonosporopsis spp. and C. orbiculare. It was less likely for C. orbiculare to occur on a leaf when Stagonosporopsis spp. was present on that leaf. In fall 2016, Stagonosporopsis spp. and Myrothecium s.l. were dissociated with one another $(P<0.0001)$, and there was a positive association between Stagonosporopsis spp. and viral pathogens $(P=0.0002)$.

Apart from Stagonosporopsis spp., P. xanthii also had several significant associations with other pathogens throughout the survey. In spring 2016 , there were dissociations with $C$. citrullina $(P=0.0001)$ and $C$. orbiculare $(P=0.0394)$, and in fall 2016 there was a dissociation with Myrothecium s.l. $(P=0.0002)$ in addition to the already mentioned positive association with Stagonosporopsis spp. (Table 6).

Table 4. Occurrence of pathogens in combinations on watermelon leaves in spring 2015 and 2016

\begin{tabular}{|c|c|c|}
\hline \multirow[b]{2}{*}{ Pathogen combination ${ }^{\mathbf{a}}$} & \multicolumn{2}{|c|}{ Percentage of leaves } \\
\hline & 2015 & 2016 \\
\hline None & 28.06 & 30.21 \\
\hline Stagonosporopsis & 25.63 & 21.83 \\
\hline Podosphaera & 8.00 & 20.42 \\
\hline Pseudoperonospora & 6.19 & 0.00 \\
\hline Cercospora & 1.29 & 1.12 \\
\hline Virus & 0.10 & 0.00 \\
\hline Myrothecium & 0.05 & 0.08 \\
\hline Colletotrichum & 0.00 & 6.04 \\
\hline Podosphaera + Stagonosporopsis & 9.96 & 14.08 \\
\hline Pseudoperonospora + Stagonosporopsis & 7.29 & 0.00 \\
\hline Cercospora + Stagonosporopsis & 3.14 & 1.75 \\
\hline Pseudoperonospora + Podosphaera & 2.57 & 0.00 \\
\hline Cercospora + Pseudoperonospora & 0.52 & 0.00 \\
\hline Cercospora + Podosphaera & 0.48 & 0.67 \\
\hline Colletotrichum + Stagonosporopsis & 0.05 & 1.21 \\
\hline Colletotrichum + Podosphaera & 0.00 & 0.33 \\
\hline Myrothecium + Podosphaera & 0.00 & 0.21 \\
\hline Myrothecium + Stagonosporopsis & 0.00 & 0.17 \\
\hline Cercospora + Colletotrichum & 0.00 & 0.08 \\
\hline Cercospora + Myrothecium & 0.00 & 0.04 \\
\hline Colletotrichum + Myrothecium & 0.00 & 0.04 \\
\hline $\begin{array}{l}\text { Pseudoperonospora }+ \text { Podosphaera }+ \\
\text { Stagonosporopsis }\end{array}$ & 4.76 & 0.00 \\
\hline $\begin{array}{l}\text { Cercospora }+ \text { Podosphaera }+ \\
\text { Stagonosporopsis }\end{array}$ & 0.86 & 1.08 \\
\hline $\begin{array}{l}\text { Cercospora }+ \text { Pseudoperonospora }+ \\
\text { Stagonosporopsis }\end{array}$ & 0.48 & 0.00 \\
\hline $\begin{array}{l}\text { Cercospora }+ \text { Pseudoperonospora }+ \\
\text { Podosphaera }\end{array}$ & 0.14 & 0.00 \\
\hline $\begin{array}{l}\text { Colletotrichum }+ \text { Podosphaera }+ \\
\text { Stagonosporopsis }\end{array}$ & 0.00 & 0.25 \\
\hline $\begin{array}{l}\text { Myrothecium + Podosphaera }+ \\
\text { Stagonosporopsis }\end{array}$ & 0.00 & 0.17 \\
\hline $\begin{array}{l}\text { Cercospora }+ \text { Colletotrichum }+ \\
\text { Stagonosporopsis }\end{array}$ & 0.00 & 0.04 \\
\hline $\begin{array}{l}\text { Cercospora }+ \text { Myrothecium }+ \\
\text { Stagonosporopsis }\end{array}$ & 0.00 & 0.04 \\
\hline Cercospora + Colletotrichum + Podosphaera & 0.00 & 0.04 \\
\hline $\begin{array}{l}\text { Cercospora }+ \text { Pseudoperonospora }+ \\
\text { Podosphaera }+ \text { Stagonosporopsis }\end{array}$ & 0.48 & 0.00 \\
\hline $\begin{array}{l}\text { Cercospora }+ \text { Podosphaera }+ \text { Myrothecium }+ \\
\text { Stagonosporopsis }\end{array}$ & 0.00 & 0.04 \\
\hline $\begin{array}{l}\text { Cercospora }+ \text { Colletotrichum }+ \\
\text { Podosphaera }+ \text { Stagonosporopsis }\end{array}$ & 0.00 & 0.04 \\
\hline Total number of leaves & 2099 & 2400 \\
\hline
\end{tabular}

Fungicides applied in fall seasons. On the 11 fields sampled in fall 2016, a total of 16 different fungicides was applied within 2 weeks prior to sampling. Seven of these were effective against GSB. In fall 2016, all but one field received at least two fungicides effective against GSB. On the four fields sampled in fall 2017, a total of 12 different fungicides was applied within the 2 weeks prior to sampling. Of these fungicides, three were effective against GSB. All four fields sampled in fall 2017 received at least three fungicides effective against GSB. All four were treated with cyprodinil, a FRAC

Table 5. Occurrence of pathogens in combinations on watermelon leaves in fall 2016 and 2017

\begin{tabular}{|c|c|c|}
\hline \multirow[b]{2}{*}{ Pathogen combination $^{a}$} & \multicolumn{2}{|c|}{ Percentage of leaves } \\
\hline & 2016 & 2017 \\
\hline Stagonosporopsis & 38.82 & 9.25 \\
\hline None & 24.09 & 38.25 \\
\hline Myrothecium & 7.18 & 16.50 \\
\hline Podosphaera & 2.36 & 0.75 \\
\hline Cercospora & 0.82 & 0.00 \\
\hline Colletotrichum & 0.45 & 3.25 \\
\hline Virus & 0.27 & 1.00 \\
\hline Corynespora & 0.00 & 5.50 \\
\hline Pseudoperonospora & 0.00 & 0.25 \\
\hline Podosphaera + Stagonosporopsis & 14.91 & 3.75 \\
\hline Stagonosporopsis + Virus & 3.82 & 0.25 \\
\hline Myrothecium + Stagonosporopsis & 3.18 & 3.50 \\
\hline Cercospora + Podosphaera & 0.73 & 0.00 \\
\hline Colletotrichum + Stagonosporopsis & 0.73 & 1.00 \\
\hline Cercospora + Stagonosporopsis & 0.45 & 0.00 \\
\hline Colletotrichum + Myrothecium & 0.09 & 1.25 \\
\hline Corynespora + Myrothecium & 0.00 & 3.25 \\
\hline Corynespora + Stagonosporopsis & 0.00 & 3.25 \\
\hline Colletotrichum + Corynespora & 0.00 & 0.50 \\
\hline Colletotrichum + Podosphaera & 0.00 & 0.50 \\
\hline Corynespora + Podosphaera & 0.00 & 0.25 \\
\hline Myrothecium + Pseudoperonospora & 0.00 & 0.25 \\
\hline Cercospora + Podosphaera + Myrothecium & 1.91 & 0.00 \\
\hline $\begin{array}{l}\text { Myrothecium }+ \text { Podosphaera }+ \\
\text { Stagonosporopsis }\end{array}$ & 0.18 & 0.75 \\
\hline $\begin{array}{l}\text { Corynespora }+ \text { Podosphaera }+ \\
\text { Stagonosporopsis }\end{array}$ & 0.00 & 1.75 \\
\hline $\begin{array}{l}\text { Colletotrichum }+ \text { Corynespora }+ \\
\text { Stagonosporopsis }\end{array}$ & 0.00 & 0.75 \\
\hline $\begin{array}{l}\text { Colletotrichum }+ \text { Corynespora }+ \\
\text { Myrothecium }\end{array}$ & 0.00 & 0.75 \\
\hline Corynespora + Myrothecium + Podosphaera & 0.00 & 0.50 \\
\hline Cercospora + Corynespora + Myrothecium & 0.00 & 0.25 \\
\hline $\begin{array}{l}\text { Cercospora }+ \text { Corynespora }+ \\
\text { Stagonosporopsis }\end{array}$ & 0.00 & 0.25 \\
\hline $\begin{array}{l}\text { Colletotrichum }+ \text { Corynespora }+ \\
\text { Pseudoperonospora }\end{array}$ & 0.00 & 0.25 \\
\hline $\begin{array}{l}\text { Colletotrichum }+ \text { Corynespora }+ \\
\text { Podosphaera }\end{array}$ & 0.00 & 0.25 \\
\hline $\begin{array}{l}\text { Colletotrichum }+ \text { Myrothecium }+ \\
\text { Podosphaera }\end{array}$ & 0.00 & 0.25 \\
\hline $\begin{array}{l}\text { Colletotrichum }+ \text { Myrothecium + } \\
\text { Stagonosporopsis }\end{array}$ & 0.00 & 0.25 \\
\hline $\begin{array}{l}\text { Colletotrichum }+ \text { Podosphaera }+ \\
\text { Stagonosporopsis }\end{array}$ & 0.00 & 0.25 \\
\hline $\begin{array}{l}\text { Corynespora }+ \text { Myrothecium }+ \\
\text { Stagonosporopsis }\end{array}$ & 0.00 & 0.25 \\
\hline Corynespora + Stagonosporopsis + Virus & 0.00 & 0.25 \\
\hline $\begin{array}{l}\text { Stagonosporopsis }+ \text { Podosphaera }+ \\
\text { Colletotrichum }+ \text { Corynespora }\end{array}$ & 0.00 & 0.50 \\
\hline $\begin{array}{l}\text { Stagonosporopsis }+ \text { Podosphaera }+ \\
\text { Corynespora }+ \text { Myrothecium }\end{array}$ & 0.00 & 0.25 \\
\hline Total number of leaves & 1100 & 400 \\
\hline
\end{tabular}

${ }^{\text {a }}$ Combination of pathogens that were present on a leaf. Virus = Papaya ringspot virus and Zucchini yellow mosaic virus in 2016 and a begomovirus in 2017. 
group 9 fungicide, and fludioxonil, a FRAC group 12 fungicide (Table 7).

\section{Discussion}

In this study, a total of 5,999 symptomatic leaves from 60 fields in the main watermelon growing counties in South Carolina were examined for foliar pathogens in four seasons from spring 2015 to fall 2017. To the best of our knowledge, this study is the first multiseason survey of foliar diseases of watermelon in the United States with an appropriate underlying sampling design and statistical analysis. The overall most prevalent pathogen was Stagonosporopsis spp., the causal agent of GSB. The fact that an additional 20 to $35 \%$ of leaves had typical symptoms of GSB in the fall seasons of 2016 and 2017 indicates that Stagonosporopsis spp. was even more prevalent than could be estimated in this study. The lack of sporulation of Stagonosporopsis spp. as observed in the fall seasons in 2016 and 2017 might have been caused by the application of fungicides. The fact that the majority of fields received three or more applications of fungicides with activity against Stagonosporopsis spp. within a 2-week period prior to sampling supports this explanation (Rennberger et al. unpublished). Inhibitory effects of fungicides on the sporulation of fungal pathogens have been shown in previous studies. Quinoneoutside-inhibitor fungicides were found to reduce sporulation of the brown rot pathogen Monilinia fructicola of peaches. The sporulating area on fruits and twig cankers was reduced 50 to $70 \%$, while the colony growth reduction was only $\leq 12 \%$ (Burnett et al. 2010). Similarly, tricyclazole and azoxystrobin were shown to reduce the sporulation of Magnaporthe oryzae, the rice blast fungus (Kunova et al. 2013). Based on the observations in this study, we are examining the effects of fungicides on sporulation by Stagonosporopsis spp.

The overall second most prevalent pathogen was $P$. xanthii, which causes powdery mildew of cucurbits. The high occurrence of $P$. xanthii, especially in the more humid fall seasons was somewhat unexpected but an important observation. In spring 2016, the frequency of leaves with $P$. xanthii and the estimated probability of occurrence of this pathogen were almost as high as for Stagonosporopsis spp. Occurrence of $P$. xanthii was comparable to Stagonosporopsis spp. in spring 2016. The majority of the watermelon

Table 6. Associations between pathogen pairs on watermelon leaves collected in 2015 and 2016

\begin{tabular}{|c|c|c|c|c|c|c|c|c|}
\hline \multirow[b]{2}{*}{ Pathogen } & \multirow[b]{2}{*}{ Season, year } & & \multicolumn{3}{|c|}{ Stagonosporopsis spp. } & \multicolumn{3}{|c|}{ P. xanthii } \\
\hline & & & Absent & Present & $P$ value $^{\text {a }}$ & Absent & Present & $P$ value \\
\hline \multirow[t]{2}{*}{ Cercospora citrullina } & Spring 2015 & Absent & $944^{\mathrm{b}}$ & 1000 & $<0.0001$ & 1413 & 531 & 0.6511 \\
\hline & & Present & 51 & 104 & & 114 & 41 & \\
\hline \multirow[t]{2}{*}{ Cercospora citrullina } & Spring 2016 & Absent & 1376 & 905 & $<0.0001$ & 1430 & 851 & 0.0001 \\
\hline & & Present & 47 & 72 & & 74 & 45 & \\
\hline \multirow[t]{2}{*}{ Colletotrichum orbiculare } & Spring 2016 & Absent & 1266 & 940 & 0.0360 & 1326 & 880 & 0.0394 \\
\hline & & Present & 157 & 37 & & 178 & 16 & \\
\hline \multirow[t]{2}{*}{ Podosphaera xanthii } & Fall 2016 & Absent & 362 & 517 & $<0.0001$ & n.a. ${ }^{\mathrm{c}}$ & n.a. & n.a. \\
\hline & & Present & 34 & 187 & & n.a. & n.a. & n.a. \\
\hline \multirow[t]{2}{*}{ Myrothecium s.1. } & Fall 2016 & Absent & 316 & 667 & $<0.0001$ & 764 & 219 & 0.0002 \\
\hline & & Present & 80 & 37 & & 115 & 2 & \\
\hline \multirow[t]{2}{*}{ Virus } & Fall 2016 & Absent & 393 & 662 & 0.0002 & 834 & 221 & n.c. ${ }^{d}$ \\
\hline & & Present & 3 & 42 & & 45 & 0 & \\
\hline
\end{tabular}

a The probability of a greater Rao-Scott $\chi^{2}$ for the proportions of the two pathogens.

${ }^{b}$ Numbers are total numbers of leaves in designated category in that season.

${ }^{\mathrm{c}}$ n.a. $=$ not applicable.

${ }^{\mathrm{d}}$ n.c. $=$ not computable. This pathogen pair never occurred together on the same leaf.

Table 7. Fungicides applied within 2 weeks prior to sampling in watermelon fields sampled in fall 2016 and fall $2017^{\mathrm{a}}$

\begin{tabular}{|c|c|c|c|c|}
\hline \multirow[b]{2}{*}{ Fungicide } & \multirow[b]{2}{*}{ FRAC code ch $^{b}$} & \multirow[b]{2}{*}{ Effective against GSB ${ }^{c}$} & \multicolumn{2}{|c|}{ Number of fields } \\
\hline & & & Fall 2016 & Fall 2017 \\
\hline Azoxystrobin & 11 & No & 1 & 2 \\
\hline Boscalid & 7 & No & 2 & 2 \\
\hline Copper & M & No & 2 & 0 \\
\hline Chlorothalonil & M & Yes & 2 & 0 \\
\hline Cyazofamid & 21 & No & 6 & 2 \\
\hline Cyflufenamid & U6 & No & 2 & 0 \\
\hline Cyprodinil & 9 & Yes & 3 & 4 \\
\hline Difenoconazole & 3 & Yes & 3 & 0 \\
\hline Fludioxonil & 12 & Yes & 1 & 4 \\
\hline Fluopyram & 7 & Yes & 6 & 0 \\
\hline Mancozeb & M & Yes & 9 & 2 \\
\hline Mefenoxam & 4 & No & 0 & 2 \\
\hline Oxathiapiprolin & 49 & No & 0 & 2 \\
\hline Phosphonate & 33 & No & 2 & 0 \\
\hline Propamocarb & 28 & No & 0 & 2 \\
\hline Pyraclostrobin & 11 & No & 2 & 4 \\
\hline Quinoxyfen & 13 & No & 2 & 0 \\
\hline Tebuconazole & 3 & Yes & 7 & 3 \\
\hline Thiophanate-methyl & 1 & No & 0 & 2 \\
\hline Zoxamide & 22 & No & 2 & 0 \\
\hline
\end{tabular}

a Eleven and four fields were sampled in fall 2016 and 2017, respectively.

${ }^{\mathrm{b}}$ FRAC $=$ Fungicide Resistance Action Committee.

${ }^{\mathrm{c}}$ GSB $=$ Gummy stem blight. Classification based on Kemble et al. (2018). 
cultivars planted in the fields sampled in this study were triploid cultivars, which were found to be less susceptible to powdery mildew than diploid cultivars (Keinath and Hassel 2000). Nonetheless, powdery mildew consistently was one of the most prevalent diseases found in this survey.

Overall, the estimates for the probability of occurrence in the state were low to very low for the other six pathogens that were found in this survey. Apart from C. citrullina, which occurred in every season, all pathogens other than the two most prevalent ones were absent in at least one season. Cercospora leaf spot was reported to occur along with anthracnose, GSB, and downy mildew on watermelon in research plots in Maryland in 2012 and 2013 (Everts et al. 2016). The occurrence of $P$. cubensis in this study was low and can be characterized as sporadic, since it was not found in the two seasons in 2016 and only at a very minor level in fall 2017. Apart from four fields where $P$. cubensis was the predominant pathogen, it also occurred infrequently on cucumbers in North Carolina. However, the survey by Peterson and Campbell in the late 1990s was done before the introduction of the A1 mating type, which is very virulent on cucumber (Holmes et al. 2015; Thomas et al. 2017c). Consistent with the suggestion by Peterson and Campbell (2002), this sporadic occurrence that is difficult to predict is most likely due to the reliance on windborne dissemination and the lack of overwintering in the Carolinas by the pathogen (Hausbeck 2017; Holmes et al. 2015). Another possible explanation for the infrequent occurrence of this pathogen might be that there are two distinct, genetic lineages of $P$. cubensis with host specialization. A distinct genetic cluster within lineage 1 was predominantly found on C. lanatus (Thomas et al. 2017a, c). This particular cluster may not be as common as isolates pathogenic on other cucurbits.

Peterson and Campbell (2002) examined 5,400 cucumber leaves with leaf spots in North Carolina from 1996 to 1998. In contrast to the results of the present survey, C. orbiculare was the most prevalent pathogen in two of the three seasons (1996 and 1998) and in a majority of the fields included in their study, while Stagonosporopsis spp. (formerly D. bryoniae) was the predominant pathogen in 1997 only. Overall, Stagonosporopsis spp. was the second most frequent pathogen in the survey in North Carolina. It was the most prevalent pathogen in 2 of 6,7 of 18 , and 6 of 24 sites sampled. The greater occurrence of Stagonosporopsis spp. in the current study compared with Peterson and Campbell's (2002) survey can be explained, in part, by the fact that watermelon generally is a more susceptible crop than cucumber (Keinath 2014). The occurrence of $C$. orbiculare in South Carolina throughout the present study was very low; the $<4 \%$ estimated probability on watermelon fields in the state is significantly lower than that of Stagonosporopsis spp. and P. xanthii. With regards to $P$. xanthii, there is a stark difference between Peterson and Campbell's study and the present one. While there was no observation of this pathogen on cucumbers in North Carolina, it was a major pathogen in our survey, second only to Stagonosporopsis spp. The likely explanation for this is that cucumber growers in North Carolina planted cultivars resistant to powdery mildew (Peterson and Campbell 2002). On the other hand, there is currently only a single commercial watermelon cultivar resistant to powdery mildew, Lemon Krush, and it was not planted in any of the 60 fields sampled for this survey (Kemble et al. 2018).

The prevalence of Stagonosporopsis spp., a pathogen dependent on humid conditions, and P. xanthii, a pathogen capable of development under drier conditions, was clearly influenced by the environmental conditions that prevailed during sampling (Keinath 2017b; McGrath 2017). In spring 2016, the combined rainfall in June and July was less than half of that of the previous year, while fall 2016 was the most humid season with somewhat lower temperatures (Table 2). The estimated occurrence of Stagonosporopsis spp. dropped almost $15 \%$ from spring 2015 to spring 2016 and then rose more than $20 \%$ in fall 2016, above its level in spring 2015. The estimated occurrence of $P$. xanthii, however, followed a reverse trend. From spring 2015 to spring 2016, it rose almost 9\% from where it dropped more than $13 \%$ below its level in spring 2015 . The drier conditions in spring 2016 thus favored $P$. xanthii.
In the survey by Peterson and Campbell (2002), C. cassiicola occurred in every season and was the most prevalent pathogen in four fields that were sampled in 1997. In contrast, the present study is the first report of C. cassiicola on watermelon in South Carolina. Apart from this study, there is only one other U. S. state, North Carolina, where watermelon was reported as a host of this pathogen (Grand 1985; Farr and Rossman 2018). This indicates that the isolates of C. cassiicola present in the Carolinas might have a unique host adaptation that enables them to utilize watermelon as an additional host. Considering the wide host range of more than 530 plant species, and the fact that there are many different host range and host specificity patterns among isolates of $C$. cassiicola, it appears possible that only a small subset of isolates in a small geographic region would be adapted to infect watermelon (Cutrim and Silva 2003; Dixon et al. 2009; Farr and Rossman 2018; Onesirosan et al. 1974).

Peterson and Campbell (2002) tested associations between pathogen pairs using a 2-by-2 contingency table $\chi^{2}$ analysis whenever pathogens occurred together at least five times in a field. No such restriction was used in the present study; instead, all leaves were included to test pathogen associations, separately for each season. Peterson and Campbell (2002) found significant associations for six different pathogen pairs. A negative association between $C$. orbiculare and Stagonosporopsis spp. accounted for more than half of them and occurred in all three seasons. In the current study, associations between pathogen pairs were analyzed using a Rao-Scott $\chi^{2}$ test, which includes adjustments necessary to account for effects of clustering in the survey design, which can otherwise impact the significance level of the test (Rao and Scott 1984, 1987). Turechek and Madden (2000) used the Jaccard similarity index to analyze the association between leaf blight caused by Phomopsis obscurans and leaf spot caused by Ramularia grevilleana (syn. Mycosphaerella fragariae) on strawberries. They argued that the method of the Jaccard similarity index is more suitable to analyze associations between plant pathogens, because it does not use information of sampling units when neither pathogen occurs and because it does not assume that the pathogens are randomly distributed. The Rao-Scott test used in this study, however, has the advantage of accounting for the sampling design and a more straightforward estimation method of standard errors compared with the Jaccard similarity index. Turechek and Madden (2000) found that $P$. obscurans and $R$. grevilleana were distributed independently and that there was a general lack of cooccurrence between the two pathogens. Many studies have found aggregation of plant pathogens, but random spatial patterns of diseases also are not uncommon. Oerke et al. (2010) studied the spatial patterns of Fusarium head blight pathogens in wheat fields and found that most species of Fusarium spp. were distributed randomly. Their results indicate that spatial distributions of plant pathogens are influenced by many factors such as inoculum source, spore type, kind of dispersal, host availability, and microclimate. Species that depended on splash dispersal tended to be more aggregated, whereas species that relied on wind dispersal had a predominantly random distribution (Oerke et al. 2010). Especially for wind-dispersed foliar pathogens, such as Stagonosporopsis spp., P. cubensis, P. xanthii, and C. citrullina, and aphid-transmitted viruses, the assumption of a random distribution within the sampled fields seems therefore adequate.

In spring 2016, we observed the same association Peterson and Campbell (2002) encountered so frequently. Stagonosporopsis spp. and $C$. orbiculare were dissociated with one another, meaning that it was less likely for the former to occur on the same leaf, if the latter was present on that leaf or vice versa (Table 6). Our finding of a negative association between these two pathogens in spring 2016 agrees with the report from North Carolina. Peterson and Campbell (2002) suggested that the two pathogens might occupy distinct ecological niches in the plant canopy. However, considering the great overlap of the environmental conditions required for development of the two pathogens, this seems unlikely (Monroe et al. 1997; van Steekelenburg 1982). With short leaf wetness periods, C. orbiculare may be more likely than Stagonosporopsis spp. to infect a leaf. In fall 2016, there was a positive association between Stagonosporopsis spp. and P. xanthii. Bergstrom et al. (1982) suggested that infection 
by $P$. xanthii predisposes cucurbits to infection by Stagonosporopsis spp. by facilitating nutrient release from the host that supports conidia germination. Although it has been shown that exogenous nutrients enhance spore germination and infection rates by Stagonosporopsis spp., the only positive association between the two most common pathogens in the present study, P. xanthii and Stagonosporopsis spp., was in fall 2016. It is possible that environmental conditions favorable for the development of both pathogens promoted their cooccurrence rather than a direct synergism between the two (Table 2) (Chiu and Walker 1949; Keinath and DuBose 2012; Svedelius and Unestam 1978). On the other hand, $P$. xanthii was negatively associated with three pathogens that require leaf wetness for infection, namely $C$. citrullina, $C$. orbiculare, and Myrothecium s.l., which implies that powdery mildew was less likely to occur in wet microenvironments that favored these pathogens. In general, a significant positive association does not allow for interpretation about which pathogen infected a leaf first nor which pathogen wields the main influence on the association.

Of the 80 isolates of Stagonosporopsis spp. cultured and identified to species level, $10 \%$ were identified as $S$. caricae, while the remaining isolates were identified as $S$. citrulli. S. cucurbitacearum was not found. This constitutes the first report of $S$. caricae in South Carolina. Among this subset of isolates, the frequency of $S$. caricae was much higher than previously reported in the southeastern United States. Brewer et al. (2015) genotyped 600 isolates of Stagonosporopsis spp. from Georgia and identified only $1 \%$ as $S$. caricae. All isolates were collected from a single field in Tift County in 2013. The following year, Li and Brewer (2016) reported a slightly higher occurrence of $S$. caricae, $3.6 \%$ of 528 isolates. These isolates originated from Tift and Cook counties in Georgia in 2013 and 2014, respectively, in which they represented 4 and $20 \%$ of the sampled isolates, respectively (Li and Brewer 2016). S. caricae was not found in two fields in Colleton County, South Carolina, that were sampled in 2012 and 2013 (Li and Brewer 2016). With 25 and $21.4 \%$ of isolates identified as $S$. caricae in Barnwell and Beaufort Counties in spring 2015, the proportion of isolates that were identified as that species was somewhat higher than in the two Georgia counties. On the other hand, $S$. caricae was not found in the other seasons and counties from which isolates were saved and tested (Hampton County in spring 2016 and Beaufort County in fall 2017). As with the sampling done by Li and Brewer (2016), it appears that the distribution of S. caricae in the southeastern United States is quite heterogeneous, and larger numbers of samples would be necessary to determine more accurately the extent of its occurrence and distribution. Analogous to the detection of isolates of a fungal plant pathogen resistant to a fungicide, the probability of detecting $S$. caricae in a sampling is dependent on the true frequency of $S$. caricae in the sampled population and the sample size. For instance if the true frequency is $1 \%$ and a sample size of 10 is chosen, the chance of not detecting $S$. caricae would be $90.4 \%$. For the current example of an assumed true frequency of $S$. caricae of $2.2 \%$ (based on the average between Brewer et al. 2015 and Li and Brewer 2016) and a sample size of 80, the chance of detecting at least one isolate of $S$. caricae is $83.1 \%$ (Russell 2003).

We detected no apparent effect of applications of triazole fungicides in South Carolina watermelon fields on the occurrence of S. caricae. $\mathrm{Li}$ and Brewer (2016) reported isolates of S. caricae highly resistant to the triazole fungicide tebuconazole in Georgia and suggested that selection of resistant isolates driven by continuous use of tebuconazole in the southeastern United States could lead to a change in the species composition of Stagonosporopsis spp. causing GSB in the region. Our findings do not support such a trend, because the field in Barnwell County where 25\% of Stagonosporopsis spp. were identified as $S$. caricae in 2015 was treated twice with tebuconazole within 2 weeks prior to sampling, while the field in Beaufort County where $27 \%$ of isolates were found to be $S$. caricae in 2015 did not receive any triazole fungicide treatment prior to sampling. No isolates of $S$. caricae were found in the field in Hampton County in spring 2016, which was not treated with tebuconazole, nor from two fields in Beaufort County, which were sprayed with tebuconazole once before the fields were sampled. Although the sample size in this study was small to draw strong conclusions, the results do not indicate that isolates of $S$. caricae occur more frequently in fields that were treated with tebuconazole. A possible explanation for this could be the general low efficacy of tebuconazole in controlling GSB (Keinath 2015b, Keinath et al. 2001).

Work is underway to identify the species of Stachybotriaceae, referred to as Myrothecium s.l., found on watermelon leaves in this study, determine their virulence on cucurbits, and characterize the genetic variability among the collected isolates. Since this family of fungi is notorious for its genetic diversity and the difficulty associated with the identification of its members, the conundrum of false identifications and assigned names will be addressed (Lombard et al. 2016).

In conclusion, this survey shows that GSB and powdery mildew are the main foliar diseases on watermelon in South Carolina. Management programs for watermelon should therefore focus on these two diseases. Changes to grower recommendations based on our results have been implemented. This survey is the first report of C. cassicola and S. caricae on watermelon in South Carolina and of one or more species within Myrothecium s.l. Appropriately designed field surveys have the potential to unravel new and emerging diseases and improve management practices for many other crops as well.

\section{Acknowledgments}

We thank V. B. DuBose, C. Conrad, H. Mauk, M. Rushton, and J. Yeargin for technical assistance and the South Carolina Agricultural Society for supplying the Thomas Heyward Jr. Graduate Fellowship to G. Rennberger.

\section{Literature Cited}

Ali, A., Mohammad, O., and Khattab, A. 2012. Distribution of viruses infecting cucurbit crops and isolation of potential new virus-like sequences from weeds in Oklahoma. Plant Dis. 96:243-248.

Bergstrom, G. C., Knavel, D. E., and Kúc, J. 1982. Role of insect injury and powdery mildew in the epidemiology of the gummy stem blight disease of cucurbits. Plant Dis. 66:683-686.

Brewer, M. T., Rath, M., and Li, H.-X. 2015. Genetic diversity and population structure of cucurbit gummy stem blight fungi based on microsatellite markers. Phytopathology 105:815-824.

Bruton, B. D., and Fish, W. W. 2017. Crater rot. Pages 94-96 in: Compendium of Cucurbit Diseases and Pests, 2nd ed. A. P. Keinath, W. M. Wintermantel, and T. A. Zitter, eds. APS Press, St. Paul, MN.

Burnett, A. L., Lalancette, N., and McFarland, K. A. 2010. Effect of QoI fungicides on colonization and sporulation of Monilinia fructicola on peach fruit and blossom blight cankers. Plant Dis. 94:1000-1008.

Chiu, W. F., and Walker, J. C. 1949. Physiology and pathogenicity of the cucurbit black-rot fungus. J. Agric. Res. 78:589-615.

Coutts, B. A., and Jones, R. A. C. 2005. Incidence and distribution of viruses infecting cucurbit crops in the Northern Territory and Western Australia. Aust. J. Agric. Res. 56:847-858.

Cutrim, F. A., and Silva, G. S. 2003. Pathogenicity of Corynespora cassiicola to different plant species. Fitopatol. Bras. 28:193-194.

Dixon, L. J., Schlub, R. L., Pernezny, K., and Datnoff, L. E. 2009. Host specialization and phylogenetic diversity of Corynespora cassiicola. Phytopathology 99:1015-1027.

Everts, K. L. 2017. Cercospora leaf spot. Page 56 in: Compendium of Cucurbit Diseases and Pests, 2nd ed. A. P. Keinath, W. M. Wintermantel, and T. A. Zitter, eds. APS Press, St. Paul, MN.

Everts, K. L., Korir, R. C., and Newark, M. J. 2016. Re-evaluation of MelCast for fungicide scheduling in mid-Atlantic watermelon. Plant Health Prog. 17: $51-52$.

Farr, D. F., and Rossman, A. Y. 2018. Fungal Databases, U.S. National Fungus Collections, ARS, USDA. Available at: from https://nt.ars-grin.gov/ fungaldatabases

Grand, L. F. 1985. North Carolina Plant Disease Index. North Carolina Agric. Res. Serv. Techn. Bull. 240:1-157.

Groenewald, J. Z., Nakashima, C., Nishikawa, J., Shin, H.-D., Park, J.-H., Jama, A. N., Groenewald, M., Braun, U., and Crous, P. W. 2013. Species concepts in Cercospora: Spotting the weeds among the roses. Stud. Mycol. 75: 115-170.

Hausbeck, M. K. 2017. Downy mildew. Pages 56-58 in: Compendium of Cucurbit Diseases and Pests, 2nd ed. A. P. Keinath, W. M. Wintermantel, and T. A. Zitter, eds. APS Press, St. Paul, MN.

Holmes, G. J., Ojiambo, P. S., Hausbeck, M. K., Quesada-Ocampo, L., and Keinath, A. P. 2015. Resurgence of cucurbit downy in the United States: A watershed event for research and extension. Plant Dis. 99:428-441. 
Kable, P. F., and Ballantyne, B. J. 1963. Observation on the cucurbit powdery mildew in the Ithaca district. Plant Dis. Rep. 47:482.

Keinath, A. P. 2008. Survival of Didymella bryoniae in infested muskmelon crowns in South Carolina. Plant Dis. 92:1223-1228.

Keinath, A. P. 2014. Reproduction of Didymella bryoniae on nine species of cucurbits under field conditions. Plant Dis. 98:1379-1386.

Keinath, A. P. 2015a. Identification of races of Colletotrichum orbiculare on muskmelon in South Carolina. Plant Health Prog. https://doi.org/10.1094/ PHP-BR-15-0004

Keinath, A. P. 2015b. Baseline sensitivity of Didymella bryoniae to cyprodinil and fludioxonil and field efficacy of these fungicides against isolates resistant to pyraclostrobin and boscalid. Plant Dis. 99:815-822.

Keinath, A. P. 2017a. Anthracnose. Pages 54-56 in: Compendium of Cucurbit Diseases and Pests, 2nd ed. A. P. Keinath, W. M. Wintermantel, and T. A. Zitter, eds. APS Press, St. Paul, MN.

Keinath, A. P. 2017b. Gummy stem blight. Pages 59-60 in: Compendium of Cucurbit Diseases and Pests, 2nd ed. A. P. Keinath, W. M. Wintermantel, and T. A. Zitter, eds. APS Press, St. Paul, MN.

Keinath, A. P. 2018. Minimizing yield and quality losses in watermelon with multi-site and strobilurin fungicides effective against foliar and fruit anthracnose. Crop Prot. 106:72-78.

Keinath, A. P., and DuBose, V. B. 2012. Controlling powdery mildew on cucurbit rootstock seedlings in the greenhouse with fungicides and biofungicides. Crop Prot. 42:338-344.

Keinath, A. P., DuBose, V. B., May, W. H., III, and Cantrell, J. P. 2001. Evaluation of strobilurins and tebuconazole for control of gummy stem blight on watermelon. Fungic. Nematicide Tests 56:V119.

Keinath, A. P., and Hassel, R. L. 2000. Evaluation of diploid and triploid watermelon cultivars for field resistance to anthracnose and gummy stem blight. Biol. Cult. Tests 14:188.

Keinath, A. P., Wintermantel, W. M., and Zitter, T. A., eds. 2017. Compendium of Cucurbit Diseases and Pests, 2nd ed. APS Press, St. Paul, MN.

Kemble, J. M., Meadows, I. M., Jennings, K. M., and Walgenbach, J. F., eds. 2018. Vegetable Crop Handbook for Southeastern United States. Meister Media Worldwide Inc., Willoughby, $\mathrm{OH}$.

Köklü, G., and Yilmaz, Ö. 2006. Occurrence of cucurbit viruses on field-grown melon watermelon in the Thrace region of Turkey. Phytoprotection 87:123-130.

Kousik, C. S., Brusca, J., and Turechek, W. W. 2016. Diseases and disease management strategies take top research priority in the Watermelon Research and Development Group members survey (2014 to 2015). Plant Health Prog. 17:53-58.

Kunova, A., Pizzatti, C., and Cortesi, P. 2013. Impact of tricyclazole and azoxystrobin on growth, sporulation and secondary infection of the rice blast fungus, Magnaporthe oryzae. Pest Manag. Sci. 69:278-284.

Li, H.-X., and Brewer, M. T. 2016. Spatial genetic structure and population dynamics of gummy stem blight fungi within and among watermelon fields in the southeastern United States. Phytopathology 106:900-908.

Lombard, L., Houbraken, J., Decock, C., Samson, R. A., Meijer, M., Réblová, M., Groenewald, J. Z., and Crous, P. W. 2016. Generic hyper-diversity in Stachybotriaceae. Persoonia 36:156-246.

Mahgoub, E. 1969. Corynespora cassiicola, a new agent of maduromycetoma. J. Trop. Med. Hyg. 72:218-221.

McGrath, M. T. 2017. Powdery mildew. Pages 62-64 in: Compendium of Cucurbit Diseases and Pests, 2nd ed. A. P. Keinath, W. M. Wintermantel, and T. A. Zitter, eds. APS Press, St. Paul, MN.

Monroe, J. S., Santini, J. B., and Latin, R. 1997. A model defining the relationship between temperature and leaf wetness duration, and infection of watermelon by Colletotrichum orbiculare. Plant Dis. 81:739-742.

National Weather Service Forecast Office. 2018. Available at: https://www. weather.gov/chs/

Neufeld, K. N., Keinath, A. P., Gugino, B. K., McGrath, M. T., Sikora, E. J., Miller, S. A., Ivey, M. L., Langston, D. B., Dutta, B., Keever, T., Sims, A., and Ojiambo, P. S. 2018. Predicting the risk of cucurbit downy mildew in the eastern United States using an integrated aerobiological model. Int. J. Biometeorol. 62:655-668.

Oerke, E.-C., Meier, A., Dehne, H.-W., Sulyok, M., Krska, R., and Steiner, U. 2010. Spatial variability of Fusarium head blight pathogens and associated mycotoxins in wheat crops. Plant Pathol. 59:671-682.

Onesirosan, P. T., Arny, D. C., and Durbin, R. D. 1974. Host specificity of Nigerian and North American isolates of Corynespora cassiicola. Phytopathology 64 1364-1367.

Papayiannis, L. C., Ioannou, N., Boubourakas, I. N., Dovas, C. I., Katis, N. I., and Falk, B. W. 2005. Incidence of viruses infecting cucurbits in Cyprus. J. Phytopathol. 153:530-535.

Peterson, P. D., and Campbell, C. L. 2002. Prevalence and ecological association of foliar pathogens of cucumber in North Carolina. Plant Dis. 86:1094-1100.

Rao, J. N. K., and Scott, A. J. 1981. The analysis of categorical data from complex sample surveys: chi-squared tests for goodness of fit and independence in twoway tables. J. Am. Stat. Assoc. 76:221-230.

Rao, J. N. K., and Scott, A. J. 1984. On chi-squared tests for multiway contingency tables with cell proportions estimated from survey data. Ann. Stat. 12:46-60.

Rao, J. N. K., and Scott, A. J. 1987. On simple adjustments to chi-square tests with sample survey data. Ann. Stat. 15:385-397.

Rao, P. S. R. S. 2000. Sampling Methodologies with Applications. Chapman \& Hall/CRC, Boca Raton, FL.

Russell, P. 2003. FRAC monograph 3: Sensitivity baselines in fungicide resistance research and management. Available at: www.frac.info/docs

Sammons, B., Barnett, O. W., Davis, R. F., and Mizuki, M. K. 1989. A survey of viruses infecting yellow summer squash in South Carolina. Plant Dis. 73:401-404.

Stewart, J. E., Turner, A. N., and Brewer, M. T. 2015. Evolutionary history and variation in host range of three Stagonosporopsis species causing gummy stem blight of cucurbits. Fungal Biol. 119:370-382.

Svedelius, G., and Unestam, T. 1978. Experimental factors favouring infection of attached cucumber leaves by Didymella bryoniae. Trans. Br. Mycol. Soc. 71: 89-97.

Thomas, A., Carbone, I., Choe, K., Quesada-Ocampo, L. M., and Ojiambo, P. S. 2017a. Resurgence of cucurbit downy mildew in the United States: Insights from comparative genomic analysis of Pseudoperonospora cubensis. Ecol. Evol. 7:6231-6246.

Thomas, A., Carbone, I., Cohen, Y., and Ojiambo, P. S. 2017b. Occurrence and distribution of mating types of Pseudoperonospora cubensis in the United States. Phytopathology 107:313-321.

Thomas, A., Carbone, I., and Ojiambo, P. 2017c. Genetic structure geography and host specialization within populations of Pseudoperonospora cubensis in the United States. (Abstr.) Phytopathology 107:S5.115.

Turechek, W. W., and Madden, L. V. 2000. Analysis of the association between the incidence of two spatially aggregated foliar diseases of strawberry. Phytopathology 90:157-170.

Ullman, D. F., Cho, J. J., and German, T. L. 1991. Occurrence and distribution of cucurbit viruses in the Hawaiian Islands. Plant Dis. 75:367-370.

USDA-NASS. 2014. 2012 Census of Agriculture, United States, Summary and State Data. Available at: https://www.agcensus.usda.gov/Publications/2012/ Online Resources/Ag_Census_Web_Maps/Overview/

van Steekelenburg, N. A. M. 1982. Factors influencing external fruit rot of cucumber caused by Didymella bryoniae. Neth. J. Plant Pathol. 88:47-56.

Wasilwa, L. A., Correll, J. C., Morelock, T. E., and McNew, R. E. 1993. Reexamination of races of the cucurbit anthracnose pathogen Colletotrichum orbiculare. Phytopathology 83:1190-1198.

Williams, P. H., and Vallad, G. E. 2017. Target leaf spot. Pages 67-68 in: Compendium of Cucurbit Diseases and Pests, 2nd ed. A. P. Keinath, W. M. Wintermantel, and T. A. Zitter, eds. APS Press, St. Paul, MN.

Yamada, H., Takahashi, N., Hori, N., Asano, Y., Mochizuki, K., Ohkusu, K., and Nishimura, K. 2013. Rare case of fungal keratitis caused by Corynespora cassiicola. J. Infect. Chemother. 19:1167-1169. 